Original Artikel

Spizaetus: Jurnal Biologi dan Pendidikan Biologi

Volume 2 Nomor 3, Oktober 2021

pISSN: 2716-151X

eISSN: 2722-869X

\title{
Pengembangan LKPD Dengan Pendekatan Contextual Teaching and Learning (CTL)Terhadap Hasil Belajar Siswa Kelas VIII SMP Negeri 3 Maumere
}

\author{
Fransiska Aurelia Yusvin $^{1 *}$, Yohanes Nong Bunga ${ }^{1}$ \\ ${ }^{1}$ Program Studi Pendidikan Biologi, Fakultas Keguruan dan Ilmu Pendidikan, \\ Universitas Nusa Nipa Indonesia, Sikka, Indonesia, 86111 \\ Email*: aureliayusvin@gmail.com
}

\begin{abstract}
ABSTRAK
Penelitian ini bertujuan untuk mengetahui kelayakan Lembar Kerja Peserta Didik(LKPD) dengan pendekatan Contextual Teaching and Learning (CTL) pada materi struktur jaringan tumbuhan yang dikembangkan, mengetahui peningkatan kemampuan berpikir kritis dan hasil belajar peserta didik setelah menggunakan LKPD hasil pengembangan. Penelitian ini adalah penelitian pengembangan dengan model pengembangan 4-D. Prosedur yang diadaptasi meliputi 4 tahap: (1) Define, (2) Design, (3) Develop, dan (4) Disseminate. Teknik analisis data yang digunakan pada penelitian ini merupakan analisis deskriptif kuantitatif dan kualitatif. Hasil penelitian menyimpulkan bahwa kelayakan LKPD dilihat dari hasil penilaian validator, yaitu memperoleh nilai 192 yang termasuk dalam kategori sangat baik Berdasarkan skor pretest-posttest diperoleh gain score sebesar 0,6yang termasuk dalam kategori sedang. Hasil belajar peserta didik meningkat sebesar $66 \%$ dari kategori sangat kurang menjadi baik. Oleh karena itu lembar kerja peserta didik pada materi struktur jaringan tumbuhan layak untuk digunakan dalam pembelajaran di sekolah.
\end{abstract}

Kata Kunci: ctl, hasil belajar, lkpd

\section{PENDAHULUAN}

Pendidikan merupakan sarana utama dalam upaya meningkatkan kualitas sumber daya manusia, oleh karena itu pendidikan harus dilaksanakan dengan sebaik-baiknya, sehingga sesuai dengan tujuan pendidikan. Menurut UU no. 23 tahun 2003 menyatakan bahwa pendidikan adalah usaha sadar dan terencana untuk mewujudkan suasana belajar agar siswa secara aktif mengembangkan potensi dirinya. Tujuan pendidikan nasional adalah mencerdaskan kehidupan bangsa dan mengembangkan manusia seutuhnya, sehingga
Pendidikan turut membentuk insan Indonesia berkepribadian dan berkarakter.

Proses Pembelajaran merupakan suatu sistem, yaitu satu kesatuan komponen yang satu sama lain saling berkaitan dan saling berinteraksi untuk mencapai suatu hasil yang diharapkan secara optimal sesuai dengan tujuan yang telah ditetapkan. Keberhasilan guru dalam melaksanakan pembelajaran tergantung kepada ketepatan guru memilih model pembelajaran. Pengembangan model pembelajaran yang tepat pada dasarnya bertujuan untuk menciptakan kondisi pembelajaran yang memungkinkan 
siswa dapat belajar secara aktif dan menyenangkan.

Berdasarkan hasil observasi di SMP Negeri 3 Maumere, proses pembelajaran pada umumnya masih didominasi oleh aktivitas guru sebagai sumber utama pengetahuan dalam kegiatan belajar mengajar (KBM) dengan menggunakan lembar kerja peserta didik (LKPD) pada buku paket. Lembar Kerja Peserta Didik (LKPD) adalah salah satu perangkat pembelajaran berupa panduan peserta didik dalam melakukan kegiatan penyelidikan atau pemecahan masalah untuk pembentukan kemampuan dasar sesuai indikator hasil belajar yang ditempuh (Trianto dalam Syafaruddin, 2016). Permasalahan diatas adalah peserta didik kesulitan dalam melakukan kegiatan penyelidikan dalam pemecahan suatu masalah secara berkelompok sehingga menurunnya hasil belajar dan rendahnya kemampuan berpikir kritis peserta didik tidak terasah dengan baik.

Model pembelajaran yang digunakan dalam LKPD yaitu model pembelajaran Contextual Teaching and Learning (CTL). Peserta didik melalui bimbingan guru akan mendapatkan pengalaman penemuan konsep. Model pembelajaran Contextual Teaching and Learning (CTL) membantu peserta didik memahami materi yang diajarkan dan menerapkannya dalam kehidupan sehari-hari( Departemen Pendidikan Nasional dalam Huda, 2010).Contextual Teaching and Learning (CTL) menekankan kepada proses keterlibatan peserta didik untuk menemukan materi, artinya proses belajar diorientasikan pada proses pengalaman secara langsung. Proses pembelajaran menuntut peserta didik untuk berpikir kritis dalam menanggapi permasalahan dan persoalan yang ada terutama dalam bidang pendidikan, sehingga dapat meningkatkan hasil belajar siswa. Proses pembelajaran didalam kelas diarahkan pada kemampuan peserta didik untuk mengingat dan menimbun berbagai informasi serta peningkatan hasil belajar peserta didik tanpa dituntut untuk memahami informasi yang diingatnya itu dalam menghubungkan dengan kehidupan.

\section{METODOLOGI PENELITIAN}

Penelitian ini dilaksanakan di SMP Negeri 3 Maumere Kelurahan Wuring, Kecamatan Alok Barat, Kabupaten Sikka. pada tanggal 25 September sampai 20 Oktober tahun pelajaran 2020/2021. Model penelitian yang digunakan dalam penelitian ini adalah penelitian Eksperimen Semu dan pengembangan atau Research and Development (R\&D). Model pengembangan perangkat yang digunakan dalam penelitian ini adalah pengembangan 4D. Model pengembangan 4-D terdiri dari 4 tahapan utama yaitu; Define (pendefinisian), Design (perancangan), Develop (pengembangan), Disseminate (penyebaran) (Trianto, 2011). Tahap define (pendefinisian) meliputi analisis awal, analisis peserta didik, analisis tugas, analisis konsep, perumusan/spesifikasi tujuan pembelajaran. Tahap design (perencanaan) meliputi penyusun tes, pemilihan media, pemilihan model lembar kerja peserta didik (LKPD), Rancangan awal lembar kerja peserta didik (LKPD). Tahap develop (pengembangan) meliputi validasi produk, perbaikan produk, uji coba I, uji coba II. Tahap Disseminate (Penyebaran) merupakan tahap penyebarluasan produk hasil pengembangan.

\section{HASIL DAN PEMBAHASAN}

\section{Validasi Lembar Kerja Peserta Didik berbasis Contextual Teaching and Learning (CTL) \\ Lembar Kerja Peserta Didik (LKPD)} yang telah disusun di uji validasi oleh beberapa ahli media, ahli bahasa dan ahli materi. LKPD yang dikembangkan memiliki nilai dengan tingkat kevalidan yang berbeda, Ahli materi dan media mengkategorikan dalam kategori sangat valid dengan nilai rerata masing-masing kategori $89.125 \%$ dan $87.75 \%$ secara berurutan 
sedangkan ahli Bahasa mengkategorikan kategori valid dengan nilai 80.495 (Tabel 1). Tingkat kevalidan akan menjadi kategori valid diatas sama dengan $81 \%$ dan dibawah sama dengan $81 \%$ akan masuk dalam kategori valid (Arikunto, 2013; Ndia et al., 2021). LKPD yang valid menjadi salah satu media yang digunakan dalam rangka uji kelayakan.

Tabel 1. Hasil Validasi Lembar Kerja Peserta Didik (LKPD)

\begin{tabular}{|c|c|c|c|c|}
\hline \multirow{2}{*}{ No } & \multirow{2}{*}{ Validator } & \multicolumn{2}{|c|}{ Rata-Rata } & \multirow{2}{*}{ Kategori } \\
\hline & & Valid 1 & Validator 2 & \\
\hline 1 & Ahli Materi & 90.75 & 87.5 & Sangat Valid \\
\hline 2 & Ahli Bahasa & 78.62 & 82.37 & Valid \\
\hline 3 & Ahli Media & 88 & 87.5 & Sangat Valid \\
\hline
\end{tabular}

Dalam kajian ini Ahli media memberikan skor $87.75 \%$ menunjukan nilai yang tinggi. Kajian penelitian terdahulu menunjukan bahwa salah satu aspek yang dapat meningkatkan pengetahuan dan pemahaman peserta didik adalah ketersediaan media pendidikan dalam proses pembelajarn di kelas (Bare et al., 2021). Budiman (2017) menuturkan pada saat ini penggunaan Ilmu Pengetahuan dan Teknologi (IPTEK) berpengaruh besar terhadap kehidupan manusia pada umumnya khususnya dibidang pendidikan. Salah satu penerapan adalah dalam kajian pengembangan bahan ajar LKPD.

\section{Kelayakan Lembar Kerja Peserta Didik berbasis Contextual Teaching and Learning (CTL) \\ LKPD yang dikembangkan sebelum} disebarkan dilakukan proses apakah layak untuk digunakan dalam kajian uji kelayakan. Kelayakan Lembar Kerja Peserta Didik berbasis Contextual Teaching and Learning (CTL) masuk dalam kategori sangat layak karena berada pada rentang skor 87.91 hasil rerata nilai masingmasing peserta didik dijumlahkan dan dibagi kedalam enam orang siswa (Gambar 1). Kelayakan suatu LKPD ini dimasukkan dalam kategori layak sesuai dengan Penelitian Majid, (2014) yang memberikan nilai uji skala kecil sebesar 87\% dan Penelitian Ndia et al., (2021) memperoleh nilai uji kelayakan kelas kecil sebesar 64.8.

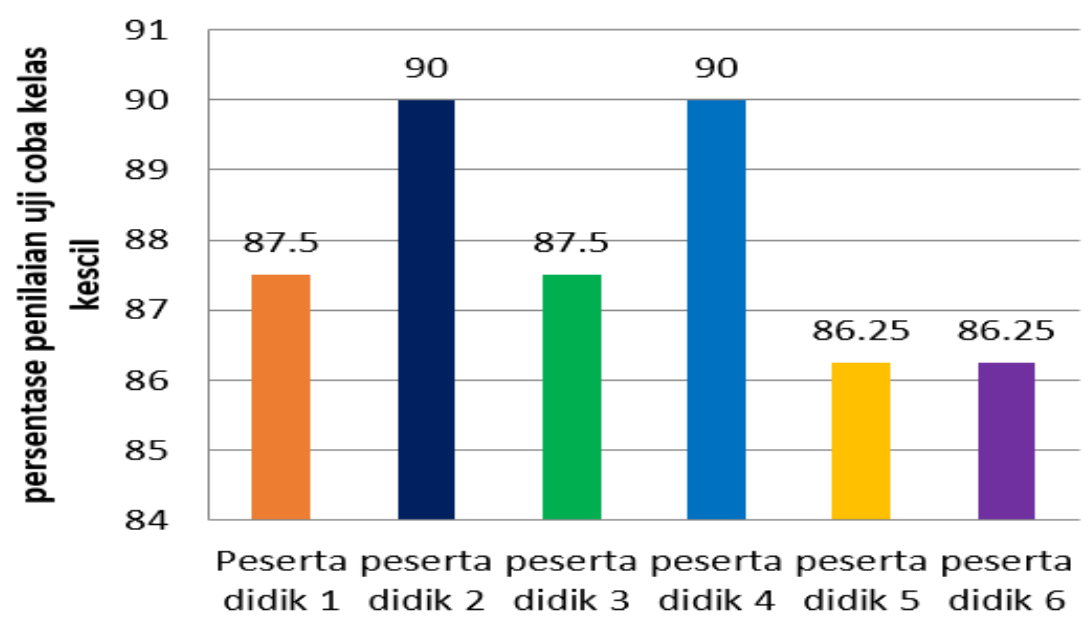

Gambar 1. Persentase Penilaian Uji Coba Kelas Kecil Oleh Peserta didik 
Beberapa kajian penelitian dalam uji kelayakan berdasarkan pendapat Arsyad, (2011), (2013) yang menyatakan bahwa bahan ajar dapat dikatakan layak digunakan apabila dilihat dari beberapa aspek adalah kelayakan isi, kebahasaan dan kelayakan penggunaan. Sesuai dengan kajian penelitian ini kami menemukan bahwa LKPD yang dikembangkan sudah mendapatkan nilai sangat layak dari aspek kelayakan isi, kebahasaan dan kelayakan penggunaan. Kemudian pengujian kepraktisan pada kelas besar diperoleh data dari 12 indikator dalam lembar angket penilaian kelayakan oleh peserta didik. Nilai rata-rata yang diperoleh dari angket respon peserta didik adalah sebesar 110 dengan kriteria sangat layak. Selanjutnya tanggapan guru dua orang guru diperoleh nilai 192 dibagi kedalam 2 poin menjadi 96 dan masuk dalam kategori sangat layak. Lembar kerja peserta didik (LKPD) diserahkan pada masing-masing validator materi, validator bahasa, validator media, dan 1 ahli praktisi untuk menghasilkan produk akhir setelah melalui proses revisi sebelum diujicobakan.
Revisi uji coba lapangan terdiri atas dua tahap, yaitu tahap uji coba kelas kecil dan kelas besar. Revisi produk pada uji coba kelas kecil berdasarkan angket hasil tanggapan guru biologi dan peserta didik. Revisi produk pada uji coba kelas besar berdasarkan angket hasil tanggapan guru biologi dan peserta didik yaitu memperbaiki produk yang kurang optimal, sehingga menghasilkan produk lembar kerja peserta didik (LKPD) pada pembelajaran biologi yang benarbenar bermutu dan berkualitas.

\section{Hasil Belajar Peserta Didik sesuai dengan Lembar Kerja Peserta Didik berbasis Contextual Teaching and Learning (CTL)}

Berdasarkan hasil pre-test gambar 4.3 kelas VIII E dengan persentase sebesar $10 \%$, nilai maksimum sebesar 70 dan nilai minimum 25 dengan kategori sangat kurang. Hasil nilai posttest dengan persentase sebesar $66 \%$, nilai maksimum 75 dan nilai minimum 45,8 dengan kategori baik (Gambar 2).

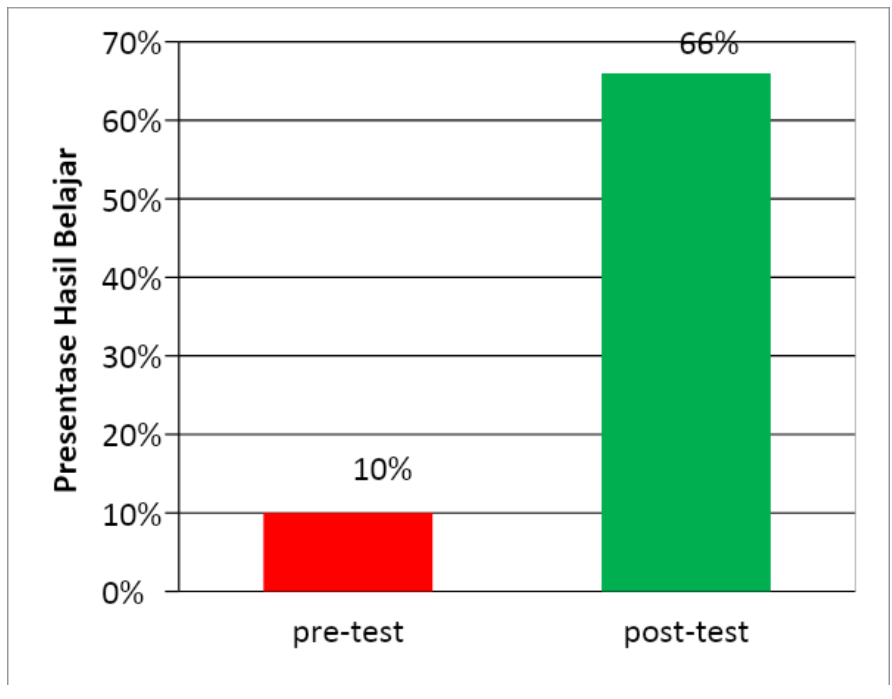

Gambar 2. Nilai Pretest dan Posttest Kelas VIII E 
Berdasarkan hasil penilaian kelayakan lembar kerja peserta didik (LKPD) dengan pendekatan Contextual Teaching and Learning (CTL) yang dikembangkan layak digunakan dalam proses pembelajaran. Kegiatan pembelajaran menggunakan lembar kerja peserta didik (LKPD) dengan pendekatan Contextual Teaching and Learning (CTL) yang dikembangkan dapat meningkatkan kemampuan berpikir kritis dan hasil belajar. Peningkatan pemahaman siswa akan dipengaruhi oleh media yang digunakan dalam suatu pembelajaran (Bare \& Sari, 2021; Hayong \& Putra, 2020; Sizi et al., 2021).

Tabel 2. Analisis Nilai Gain Skor

\begin{tabular}{cccc}
\hline Nilai & Post-Test & $\begin{array}{c}\text { Rata- } \\
\text { Rata } \\
\text { Gain }\end{array}$ & Kategori \\
\hline 39,85 & 63,71 & 0,6 & Sedang \\
\hline
\end{tabular}

Berdasarkan data rata-rata hasil belajar peserta didik pada tabel diatas dapat disimpulkan bahwa pemahaman konsep peserta didik meningkat setelah mendapatkan pembelajaran. Sehingga diperoleh faktor gain sebesar 0,6 dan berada pada kategori sedang. Penelitian Annafi, (2015) dari analisis yang telah dilakukan, diperoleh rata-rata nilai standar gain secara keseluruhan sebesar 0,55 dan diinterpretasi nilai standar gain maka peningkatan penguasaan materi berada pada kategori sedang. Pengembangan media LKPD menjadi penting karena dapat meningkatkan minat siswa dalam pembelajaran di kelas (Bahri et al., 2016; Br. Sitorus et al., 2019).

\section{Kajian Akhir Lembar Kerja Peserta Didik berbasis Contextual Teaching and Learning (CTL)}

Berdasarkan hasil penelitian yang telah diuraikan diatas, dapat diketahui bahwa penelitian Research and Development (R\&D) dengan mengacu pada procedural 4D ini telah menghasilkan sebuah produk lembar kerja peserta didik (LKPD) dengan pendekatan Contextual Teaching and Learning (CTL) pada materi struktur jaringan tumbuhan kelas VIII SMP Negeri 3 Maumere. Berdasarkan hasil analisis data validasi dan angket, lembar kerja peserta didik (LKPD) dengan pendekatan Contextual Teaching and Learning (CTL) pada materi struktur jaringan tumbuhan layak digunakan dalam pembelajaran biologi karena penyajian lembar kerja peserta didik (LKPD) dengan pendekatan Contextual Teaching and Learning (CTL) dilengkapi gambar-gambar yang berkaitan dengan kehidupan sehari-hari peserta didik sehingga dapat meningkatkan kemampuan berpikir kritis dan hasil belajar.

\section{SIMPULAN}

Berdasarkan hasil penelitian mengenai Pengembangan lembar kerja peserta didik (LKPD) dengan Pendekatan Contextual Teaching and Learning (CTL) Terhadap Hasil Belajar Siswa Kelas VIII SMP Negeri 3 Maumere diperoleh kesimpulan Hasil validasi lembar kerja peserta didik (LKPD) dengan Pendekatan Contextual Teaching and Learning (CTL) yang dikembangkan dinyatakan layak digunakan dalam pembelajaran pada materi struktur jaringan tumbuhan diperoleh rata-rata persentase secara keseluruhan sebesar $70 \%$ dengan kategori cukup kritis, hasil belajar peserta didik meningkat sebesar $60 \%$ diperoleh dari rata-rata hasil posttest. 


\section{DAFTAR PUSTAKA}

Annafi, N. (2015). Pengembangan Lembar Kegiatan Peserta Didik Berbasis Inkuiri Terbimbing Pada Materi Termokimia Kelas XI SMA/MA. Jurnal Inkuiri, 4(3), 8.

Arikunto, S. (2013). Dasar-Dasar Evaluasi Pendidikan. PT Bumi Aksara.

Arsyad, A. (2011). Media Pembelajaran. PT Raja Grafindo.

Arsyad, A. (2013). Media Pembelajaran. Rajawali Press.

Bahri, S., Syamsuri, I., \& Mahanal, S. (2016). Pengembangan Modul Keanekaragaman Hayati Dan Virus Berbasis Model Inkuiri Terbimbing Untuk Siswa Kelas X SMAN 1 Malang. Jurnal Pendidikan: Teori, Penelitian, dan Pengembangan, 1(2), 10.

Bare, Y., Putra, S. H. J., Bunga, Y. N., Mago, O. Y. T., S, M., \& Boli, Y. T. (2021). Implementasi Biology Club I di SMA Karitas Watuneso, Kecamatan Lio Timur, Kabupaten Ende. Jurnal ABDINUS: Jurnal Pengabdian Nusantara, 4(2), 321-328. https://doi.org/10.29407/ja.v4i2.15286

Bare, Y., \& Sari, D. R. T. (2021). Pengembangan Lembar Kerja Mahasiswa (LKM) Berbasis Inkuiri Pada Materi Interaksi Molekuler. BioEdUIN, 11(1), 8. https://doi.org/10.15575/bioeduin.v11i1.12077

Br. Sitorus, A. O., Kasrina, K., \& Ansori, I. (2019). Pengembangan LKPD Berdasarkan Tanaman Obat Suku Pekal. Diklabio: Jurnal Pendidikan dan Pembelajaran Biologi, 3(2), 185-194. https://doi.org/10.33369/diklabio.3.2.185-194

Budiman, H. (2017). Peran Teknologi Informasi Dan Komunikasi Dalam Pendidikan. AlTadzkiyyah: Jurnal Pendidikan Islam, $\quad 8(1), \quad 31$. https://doi.org/10.24042/atjpi.v8i1.2095

Hayong, M. S. W., \& Putra, S. H. J. (2020). Pengembangan Lembar Kerja Peserta Didik (LKPD) Berbasis Inkuiri Pada Materi Sistem Reproduksi Manusia Kelas XI SMA Development of Inquiry-Based Students' Worksheet on Human Reproductive System Subject for 11th Grade Senior High School. Spizaetus: Jurnal Biologi dan Pendidikan Biologi, 1(3), 38-49.

Huda. 2010. Model-Model Pengajaran Dan Pembelajaran. Yogyakarta: Pustaka Belajar.

Majid, A. (2014). Pembelajaran Tematik Terpadu. PT Remaja Rosdakarya.

Ndia, F. X., Mago, O. Y. T., \& Bare, Y. (2021). Pengembangan Lembar Kerja Peserta Didik (LKPD) Kooperatif Tipe Jigsaw Materi Klasifikasi Makhluk Hidup Kelas VII SMP. Quagga: Jurnal Pendidikan Dan Biologi, 13(2), 24-30. https://doi.org/10.25134/quagga.v13i2.4011 
Probowati, A \& Tenser. A, Maslikah. S. 2016. Pengembangan Lembar Kerja Siswa Berbasis Inkuiri Terbimbing Pada Materi Sistem Ekskresi Untuk Meningkatkan Hasil Belajar Siswa di SMA Negeri 1 Rejotangan Tulungagung. Jurnal Pendidikan Biologi 1 (1) :26.

Sizi, Y., Bare, Y., \& Galis, R. (2021). Pengaruh Model Pembelajaran Kooperatif Tipe Talking Stick Terhadap Keaktifan dan Hasil Belajar Kognitif Peserta Didik SMP Kelas VIII. Spizaetus: Jurnal Biologi dan Pendidikan Biologi, 2(1), 8.

Sugiyono. 2010. Metode Penelitian Kuantitatif, Kualitatif Dan R\&D. Bandung: Penerbit Alfabeta.

Widoyoko, E. P. 2014. Penilaian Hasil Belajar Disekolah. Yogyakarta : Pustaka Pelajar. 